\title{
顎関節症の耳痛発症の機序
}

\author{
中庭 敏博・松本 敏彦・岸 高生
}

\section{A Possible Mechanism of Otalgia Stemming from Temporomandibular Disorders}

\author{
Toshihiro Nakaniwa, Toshihiko Matsumoto and Takao Kishi \\ (Department of Removable Partial Prosthodontics, Nihon University School of Dentistry at Matsudo)
}

\begin{abstract}
A study was conducted to investigate the relationship between otalgia and the condyle displacement stemming from temporomandibular disorders (TMDs). Twenty-eight female patients of similar ages with TMDs were enrolled and classified into two groups: 14 subjects without any ear symptoms and the others with otalgia. Peak pressure and impedance in the middle ear were evaluated, condyle displacement at $\mathrm{P}_{1-}$ $\mathrm{P}_{5}$ was measured using axial radiograph projection and kinematic axis point displacement between preand post treatment was determined.

The differences between the two groups were statistically analyzed by Mann-Whitney U-test and Wilcoxon signed-ranks test, and significant differences between two groups were noted for the following: side difference of the lateral shift of the condyle, vector of the centric slide analyzed at kinematic axis points, and middle ear peak pressure on the disorder side, and also stapedius reflex threshold level on the opposite side. These results suggest that in TMDs either the presence or absence of otalgia is significantly related to disorders of the middle ear pressure stemming from condyle displacement.
\end{abstract}

Key words : otalgia, temporomandibular disorders, peak pressure

はじめに

顎関節症には耳鳴，めまい感，耳痛，耳閉感などの症 状がみられるが，なかでも耳痛は高頻度である。耳鼻咽 喉領域に病因が推定される所見はみられず，顎関節症状 の軽減につれて消退することが多い。顎関節の圧痛と耳 痛との間に有意な関連性を認め，顎関節症が非耳性耳痛 の最多原因との報告 ${ }^{1 ）}$ むる。従来，顎関節症にお竹る 耳痛の発症は, 後方に偏位した下顎頭の機械的圧力が顎 関節と同じ神経支配の鼓膜や鼓膜張筋への侵害刺激と なってスパズムを生じさせ ${ }^{2)}$, 口蓋帆張筋の過緊張が耳 管調節を阻害するためとされてきた ${ }^{3)}$ ５).

しかし臨床では, 関節症状が重篤で撮影画像に著し い後方偏位がみられても耳痛を訴えない顎関節症が多 く6)7, 耳痛の有無による下顎頭位の相違や顎関節症によ
る耳痛発症の機序は不明である．近年，口蓋帆張筋を運 動調節する知覚神経終末が鼓膜に存在すること, 三叉神 経節が蝸牛神経核や上オリーブ核複合体を支配するこ と ${ }^{899)}$ が報告され，咬合と耳症状との関係が注目されてい $ろ^{10)}$.

今回，大学病院や近隣総合病院の耳鼻咽喉科医により 非耳性と診断された耳痛（以下，耳痛と記す）を伴う顎 関節症, および耳痛のない顎関節症の 2 群を対象として, スプリント(歯列に装着して咬合改善を図る樹脂製副子) による下顎頭整位の治療前後に，オトガイ一頭頂方向 X 線規格撮影，鼓膜インピーダンスと中耳腔圧および耳小 骨筋の反射闇值測定から, 自覚症状の変化を検討した. また中心滑走（下顎頭位と上下歯列の嵌合位との 3 次元 的ずれ）の分析によって，自覚症状の変化と咬合との関 
連を検討したところ，多少の知見が得られたので報告す る.

\section{対象と方法}

\section{1. 対象}

対象は，耳痛を伴う顎関節症 14 例 $(43.8 \pm 11.5$ 歳, 以下, 耳痛群と記す), および耳痛のない顎関節症 14 例 (36. $1 \pm 12.7$ 歳, 以下, 非耳痛群と記す) の 2 群計 28 例 （いずれも女性）である. 2 群はいずれも顎関節 MRI 撮 影により関節円板の恒常的な位置異常を認める IIIb（非 復位性関節円板前方転位) 11) で，両側性に認めた非耳痛 群の 2 例は主訴側を患側とした (以下, 患側と記す). 耳 痛は障害顎関節と同側耳にあった (以下, 患側耳と記す)。 聴力には支障がなく検查は施行しなかったが，紹介元耳 鼻咽喉科医から，可聴閾值は正常域で鼓膜異常もないと の診断を得ている，なお，検查記録の使用については患 者の承諾を得た。

\section{2. 方法}

初診時（以下，治療前と記す）と下顎頭整位後（以下， 治療後と記す)，オトガイ一頭頂方向 X 線規格写真（以 下，体軸写真と記す）を撮影し，インピーダンスとピー ク圧および耳小骨筋反射の反射閾値（以下，反射閾値と 記す）を測定した。 また，体軸写真上の下顎頭偏位と中 心滑走 (下顎頭位と上下歯列の嵌合位との 3 次元的ずれ) を測定した。

1）下顎頭位の測定（図 1）

図上段の体軸写真上で，イヤーロッド間線（X 線フィ ルムに写し込まれた左右外耳孔に挿入する頭位固定桿の 金属芯先端を結ぶ線分）を $\mathrm{X}$ 軸，その垂直二等分線を $\mathrm{Y}$ 軸とする絶対座標を設定した。 下段図に示した下顎頭卜 レースラインの内側棘を $\mathrm{P}_{1}$, 外側棘を $\mathrm{P}_{2}$, 長軸（ $\mathrm{P}_{1} \sim$ $\mathrm{P}_{2}$ 間距離）の中点を $\mathrm{P}_{3}$, 長軸の垂直二等分線と後縁との 交点を $\mathrm{P}_{4}$, 後縁と $\mathrm{X}$ 軸に平行な接線（図中点線）の交点 を $\mathrm{P}_{5}$ と定め, 各点と $\mathrm{X}$ 軸および $\mathrm{Y}$ 軸との距離を $\mathrm{ABS}$ デ ジマチックキャリパ（精度 $0.01 \mathrm{~mm}$ ）にて読み取った.

2) 中心滑走の運動点分析

通法により, 治療後, 終末蝶番軸（下顎運動における 純粋な回転運動の仮想軸）を求め，その両端に示される 運動点 7) で中心滑走を分析した. すなわち運動分析器に よって，咬合関係の 3 次元的ずれを前後方向 $(\mathrm{SAG})$, 内 外方向（LAT）, 上下方向（VER）の運動点の移動距離と して数值化した。 これらの測定值から偏位ベクトル（以
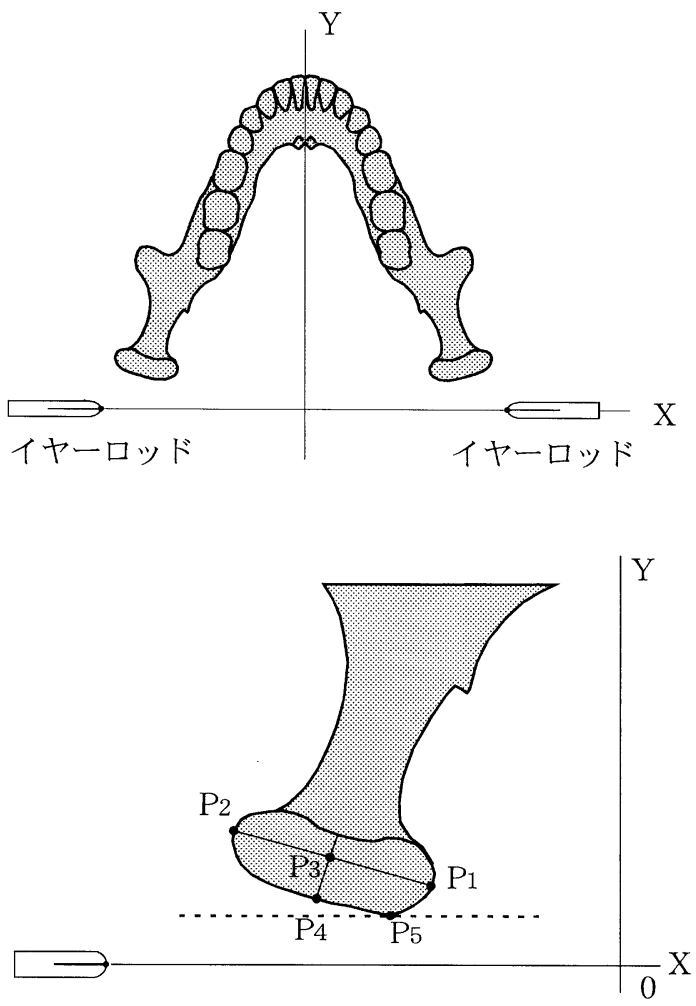

図 1 体軸写真における下顎頭偏位の測定基準と測定点 上段の図は測定基準を示す，写真に写し込まれた左右の 外耳道に挿入する頭位固定桿（イヤーロッド）の金属芯 先端を結ぶ線分（イヤーロッド間線）を X 軸，X 軸の垂 直二等分線を $\mathrm{Y}$ 軸とした。

下段の図は下顎頭トレース上の測定点を示す. $\mathrm{P}_{1}$ から $\mathrm{P}_{5}$ の各点の $\mathrm{X}$ 軸汃らの距離 (内外方向), $\mathrm{Y}$ 軸からの距離 （前後方向）を測定した.

下，LAT/SAG，VER/SAG と記す）を算出して偏位の方 向を判断した.

3)インピーダンスとピーク圧および耳小骨筋反射の測 定

治療前と治療後, インピーダンス・メーターにより患 側耳と対側耳の鼓膜インピーダンス，静的コンプライア ンスが最大值を示すときの中耳腔圧と等価の外耳道の圧 (以下，ピーク圧と記す）および耳小骨筋反射を連続して 自動測定した．用いたインピーダンス・メーターは，刺 激音 $1.0 \mathrm{kHz}$ ，刺激時間と間隔 1.5 秒で，刺激音圧 $80 \mathrm{~dB}$ SPLから $100 \mathrm{~dB}$ SPLまで $5 \mathrm{~dB}$ ごとに増強した反射波形の 振幅が自動測定される. 反射閾值は波形振幅がー $0.03 \mathrm{ml}$ 以上 ${ }^{12)}$ を示した刺激強度（dB SPL）とした。

4）データと分析

個体差の基準化の方法として, 対象個々に患側と対側 
それぞれで治療前後の測定值の差を算出し, その絶対值 を偏位量あるいは下顎整位による変化量とした（以下， 偏位量, 変化量と記す). また対象個々に, 患側の測定值 から対側の測定值を除した值の絶対值を側差とした（以 下，側差と記す)。

検定は Stat View（AVACUS 社）を用い，2 群間の比較 は Mann-Whitney の U 検定, 治療前後の比較は Wilcoxon の順位和検定により検討した。 いずれも $\mathrm{p}<0.05$ を有意 とした.

\section{結 果}

1. 耳痛は最長 7 月, 最短で 1 カ月持続していた。 8/14 例で患側耳の，2/14 例で対側耳の軽度の閉塞感が 自覚され，1/14 例に夜間の患側耳の膨満感があった。耳 痛と異常感は, bite plane（全歯接触型スプリント）装着 $1 \sim 2$ 日にて 10/14 例に軽減が自覚され, repositioning appliance (前方整位固定型スプリント)装着 7 〜 10 日にて 全例に消退が自覚された。

2. 下顎頭位では $\mathrm{P}_{1} \sim \mathrm{P}_{5}$ 点で内外方向の距離の側差に
（表 1），中心滑走では患側運動点のベクトルに（LAT/ SAG）（表 2)，2 群間の有意差を認めた.

3. ピーク圧では患側耳（表 3）および対側耳の変化量 に（表 4)，2 群間の有意差を認めた。 下顎頭整位によっ て，インピーダンスの側差では両群で，ピーク圧の側差 では耳痛群で，有意な変化を認めた（表 5).

4. 反射閾值では対側耳に 2 群間の有意差を認め（表 6)，下顎頭整位によって耳痛群では側差の有意な変化を 認めた（表 7).

\section{考察}

耳痛群は複数の耳鼻咽喉科にて投薬，理学療法を受け たが耳痛軽減は一時的で再発を繰り返し，開口時に耳痛 は増大し，11/14 例に軽度の耳閉感を伴っていた. 10/14 例は bite plane（全歯平面接触型スプリント）により軽減 が自覚されたが消退には至らず，4/14 例には変化は自覚 されなかった. repositioning appliance（前方整位固定型 スプリント）変換後，全例に消退が自覚された。これは， 耳痛群における歯列の咬合干渉（歯列における部分的接

表 1 下顎頭偏位量の側差

\begin{tabular}{|c|c|c|c|c|c|c|}
\hline & & $P_{1}$ 点 & $\mathrm{P}_{2}$ 点 & $P_{3}$ 点 & $\mathrm{P}_{4}$ 点 & $P_{5}$ 点 \\
\hline \multirow{2}{*}{ 非耳痛群 } & 内外方向 & $6.58 \pm 3.95$ & $6.20 \pm 4.01$ & $5.72 \pm 2.30$ & $6.89 \pm 3.937$ & $7.14 \pm 4.74$ \\
\hline & 前後方向 & $2.18 \pm 1.90$ & $3.12 \pm 1.97 *$ & $2.17 \pm 1.79 *$ & $2.74 \pm 1.40 \quad *$ & $2.74 \pm 1.71$ \\
\hline \multirow{2}{*}{ 耳痛群 } & 内外方向 & $3.50 \pm 2.18$ & $3.29 \pm 2.05$ & $3.29 \pm 1.85$ & $3.76 \pm 2.11$ & $3.52 \pm 2.26$ \\
\hline & 前後方向 & $2.78 \pm 2.49$ & $5.07 \pm 3.28$ & $3.56 \pm 2.30$ & $3.44 \pm 2.17$ & $2.94 \pm 1.87$ \\
\hline
\end{tabular}

Unit: $\mathrm{mm}$ Mean \pm S.D. Mann-Whitney U-test

$*: \mathrm{p}<0.05, * *: \mathrm{p}<0.01$

対象個々に，患側と対側の $\mathrm{P}_{1} \sim \mathrm{P}_{5}$ 各点の内外方向と前後方向の治療前後の測定值の差の絶対値を偏位量とし，患側と対側の測定值 の差の絶対值を側差とした。

表 2 中心滑走の運動点分析

\begin{tabular}{|c|c|c|c|c|c|c|c|c|c|c|c|}
\hline & \multicolumn{6}{|c|}{ 患側運動点 } & \multicolumn{5}{|c|}{ 対側運動点 } \\
\hline & $\begin{array}{l}\text { 前後 } \\
(\mathrm{SAG})\end{array}$ & $\begin{array}{c}\text { 内外 } \\
\text { (LAT) }\end{array}$ & $\begin{array}{c}\text { 上下 } \\
\text { (VER) }\end{array}$ & $\begin{array}{l}\text { ベクトル } \\
\text { (LAT/SAG) }\end{array}$ & & $\begin{array}{c}\text { ベクトル } \\
\text { (VER/SAG) }\end{array}$ & $\begin{array}{l}\text { 前後 } \\
(\mathrm{SAG})\end{array}$ & $\begin{array}{c}\text { 内外 } \\
\text { (LAT) }\end{array}$ & $\begin{array}{c}\text { 上下 } \\
\text { (VER) }\end{array}$ & $\begin{array}{l}\text { ベクトル } \\
\text { (LAT/SAG) }\end{array}$ & $\begin{array}{c}\text { ベクトル } \\
\text { (VER/SAG) }\end{array}$ \\
\hline 非耳痛群 & $\begin{array}{r}1.13 \\
\pm 2.31 \\
\end{array}$ & $\begin{array}{l}-0.07 \\
\pm 1.71\end{array}$ & $\begin{array}{l}-0.65 \\
\pm 3.01\end{array}$ & $\begin{array}{l}-0.40 \\
\pm 1.11\end{array}$ & 7 & $\begin{array}{r}0.77 \\
+2.24\end{array}$ & $\begin{array}{r}2.14 \\
\pm 2.66\end{array}$ & $\begin{array}{l}-0.25 \\
\pm 1.62\end{array}$ & $\begin{array}{l}-0.29 \\
\pm 2.57\end{array}$ & $\begin{array}{r}0.05 \\
\pm 1.35\end{array}$ & $\begin{array}{r}0.38 \\
+3.38\end{array}$ \\
\hline 耳痛群 & $\begin{array}{r}0.73 \\
\pm 2.09\end{array}$ & $\begin{array}{r}0.32 \\
\pm 2.25\end{array}$ & $\begin{array}{l}-1.45 \\
\pm 1.79\end{array}$ & $\begin{array}{r}1.98 \\
+4.63\end{array}$ & $j$ & $\begin{array}{r}3.14 \\
\pm 11.99\end{array}$ & $\begin{array}{r}0.39 \\
\pm 2.29\end{array}$ & $\begin{array}{l}-0.33 \\
\pm 2.36\end{array}$ & $\begin{array}{l}-1.87 \\
\pm 3.13\end{array}$ & $\begin{array}{r}0.58 \\
+1.67\end{array}$ & $\begin{array}{r}0.53 \\
\pm 2.54\end{array}$ \\
\hline
\end{tabular}

Unit: $m$ mean \pm S.D. Mann-Whitney U-test

$*: \mathrm{p}<0.05$

開口運動における下顎頭の回転軸の左右の点（運動点）を基準として，治療前後の咬合の 3 次元的ずれ（中心滑走）を患側と対側そ れぞれ前後方向 (SAG)，内外方向（LAT），上下方向（VER）の移動距離を測定した. ベクトル（LAT/SAG，VER/SAG）を算出し て偏位ベクトル（方向）とした. マイナス表示は, 前後方向では前方, 内外方向では外方, 上下方向では上方への偏位を示す. 
表 3 治療前の測定值

\begin{tabular}{lcccccc}
\hline \hline & \multicolumn{3}{c}{ 患側耳 } & & \multicolumn{2}{c}{ 対側耳 } \\
\cline { 2 - 3 } & インピーダンス $(\mathrm{ohm})$ & ピーク圧 $(\mathrm{daPa})$ & & インピーダンス $(\mathrm{ohm})$ & ピーク圧 $(\mathrm{daPa})$ \\
\hline 非耳痛群 & $1886.4 \pm 650.3$ & $-13.0 \pm 12.2$ & & & $1928.9 \pm 689.9$ & $-11.1 \pm 10.7$ \\
耳痛群 & $2559.2 \pm 1558.7$ & $-2.7 \pm 7.9$ & \lrcorner & & $2196.3 \pm 1470.0$ & $-11.4 \pm 14.8$
\end{tabular}

Mean \pm S.D. Mann-Whitney U-test

$*: \mathrm{p}<0.05$

表 4 下顎頭整位による変化量

\begin{tabular}{|c|c|c|c|c|c|}
\hline & \multicolumn{2}{|c|}{ 患側耳 } & \multicolumn{3}{|c|}{ 対側耳 } \\
\hline & インピーダンス (ohm) & ピーク圧 $(\mathrm{daPa})$ & インピーダンス（ohm） & ピーク压 (daPa) & \\
\hline 非耳痛群 & $166.4 \pm 99.8$ & $12.4 \pm 15.5$ & $237.9 \pm 185.9$ & $5.1 \pm 7.1$ & $\neg$ \\
\hline 耳痛群 & $564.5 \pm 672.2$ & $7.4 \pm 7.8$ & $299.6 \pm 295.5$ & $13.8 \pm 15.7$ & $\stackrel{N a}{\rightarrow}$ \\
\hline
\end{tabular}

Mean \pm S.D. Mann-Whitney U-test

** $: \mathrm{p}<0.01$

対象個々に患側耳と対側耳との治療前後に測定した值の差の絶対值. 下顎頭整位により変化した計算值を示す.

表 5 下顎頭整位による側差の変化

\begin{tabular}{|c|c|c|c|c|}
\hline & & 治療前 & & 治療後 \\
\hline 非耳痛群 & $\begin{array}{l}\text { インピーダンス（ohm） } \\
\text { ピーク圧（daPa） }\end{array}$ & $\begin{array}{c}570.9 \pm 366.5 \\
12.0 \pm 12.0\end{array}$ & $-* * \square$ & $\begin{array}{c}228.9 \pm 387.8 \\
4.9 \pm 3.3\end{array}$ \\
\hline 耳痛群 & $\begin{array}{l}\text { インピーダンス（ohm） } \\
\text { ピーク圧 (daPa) }\end{array}$ & $\begin{array}{c}723.2 \pm 569.7 \\
11.1 \pm 12.2\end{array}$ & $\begin{array}{l}-* *- \\
-\end{array}$ & $\begin{array}{c}96.4 \pm 95.7 \\
4.1 \pm 2.2\end{array}$ \\
\hline
\end{tabular}

Mean \pm S.D. Wilcoxon signed-ranks test

$*: \mathrm{p}<0.05, * *: \mathrm{p}<0.01$

対象個々に測定した患側耳と対側耳の測定值の差の絶対值における治療前後の比較.

表 6 治療前の反射閾値

\begin{tabular}{lcc}
\hline \hline & 患側耳 & 対側耳 \\
\hline 非耳痛群 & $83.2 \pm 6.7$ & $81.4 \pm 6.9$ \\
耳痛群 & $88.6 \pm 5.4$ & $88.2 \pm 7.0 \stackrel{*}{\lrcorner}$
\end{tabular}

Unit: dB SPL Mean \pm S.D. Mann-Whitney U-test $*: \mathrm{p}<0.05$

表 7 下顎頭整位による反射間値の側差の变化

\begin{tabular}{lcc}
\hline & 治療前 & 治療後 \\
\hline 非耳痛群 & $3.2 \pm 3.7$ & $2.1 \pm 3.2$ \\
耳痛群 & $3.2 \pm 3.7 \quad-*-1.3$
\end{tabular}

Unit: dB SPL Mean \pm S.D. Wilcoxon signed-ranks test $*: \mathrm{p}<0.05$

対象個々に測定した患側耳と対側耳の測定值の差の絶対值に おける治療前後の比較.
触, 前方および側方の滑走運動障碍）の排除や下顎の安 静維持による効果の限界，積極的な下顎頭の前下方移動 の有効性を示唆し，下顎頭位と耳痛とが関係すると考え られる。

体軸写真では 2 群の偏位量に前後方向では差がみられ ず, 顎関節側方 X 線規格写真での検討7) と同様であった. 耳痛群は, 内外方向では $\mathrm{P}_{1} \sim \mathrm{P}_{5}$ いずれでも有意に小さ <（表 1), 運動点の偏位は非耳痛群と対峙する方向を示 した (表 2). 側差が小さく一側の偏位方向（LAT/SAG） が大きい耳痛群では，下顎骨が運動点を支点として回転 しており, 運動点のすぐ斜め後上方にある下顎頭の捻れ が考えられる.下顎窩で下顎頭が捻れると, 内側棘 $\mathrm{P}_{1}$ や 後方突弯部 $\mathrm{P}_{4}$, 最後端 $\mathrm{P}_{5}$ は, 耳介側頭神経を始め tinny ligament ${ }^{3) 4)}$ が通過する錐体鼓室裂への圧力7)10) となり, 外側棘 $\mathrm{P}_{2}$ や頭頂部 $\mathrm{P}_{3}$ が関節包や外側靱帯を圧迫し関節 
痛10) や中耳腔に圧変化 ${ }^{13)}$ を起こすことが報告されている が, 関節円板後部軟組織や外側勒带後部線維の血流遅 滞や関節円板の前方転位も考えられる．田沼ら ${ }^{13)}$ は immediate side shift (外側勒帯の弛緩による下顎頭の内外 方向のぶれ）と中耳腔圧との有意な相関を報告し， Atkinson $~^{14)}$ は eminence angle(顎運動における運動点の 移動軌跡の傾斜角度）の緩急と関節円板前方転位との有 意な相関を報告しており，下顎頭位の側差（表 1）や運 動点の移動方向（表 2）と耳痛発症との間には因果関係 が推測される.

顎関節症とティンパノグラムの関係を調查した松本 ${ }^{15)}$ は，健常者 A 型 100\%の対称性が関節雑音では $32.0 \%$, 顎関節症では $6.0 \%$ と病態進行に従い減少すると報告し ている．また中耳正常の S.C.（static compliance）の側差 が $0.28 \pm 0.20 \mathrm{ml}$ にまで拡大すると障害を自覚させると 述べ，ティンパノグラムが蒷関節症の判断指標となると 報告している.われわれの耳痛群の S.C. の側差は集計す ると $0.27 \pm 0.41 \mathrm{ml}$ となり松本 ${ }^{15)}$ の範囲に一致した. わ れわれの耳痛群は, 鼓膜や伝音機能に異常が認められず, 治療前，治療後のいずれの值も耳鼻咽喉科学では正常範 囲とされる $0.25 \mathrm{cc}$ 以内 ${ }^{16)}$ にある. 反射閾值もまた正常 範囲の $70 \sim 110 \mathrm{~dB}^{16)}$ にある. したがってわれわれの対 象における治療前後の測定值の変化は下顎頭整位による 効果と考えられ，中耳正常を前提条件としたティンパノ グラムや耳小骨筋反射測定は，顎関節症の診断や咬合治 療評価における筋神経的な判断指標となると考えられ る. Otomandibular syndrome (顎耳症候群) におけるティ ンパノグラムではインピーダンスの上昇がみられ，それ は鼓膜の過緊張によるものであろうとの報告がみられる が5)，われわれの症例分析ではインピーダンスの測定值 と耳痛の有無との有意な関連性はみられなかった(表3). しかし, 顎関節症状の軽快に伴いインピーダンスが 2 群 とも有意に減少したことから（表 4)，インピーダンスと 顎関節症との間には因果関係があると考えられる. 患側 耳のピーク圧の測定值には 2 群間で有意差が認められた (表 3)。ピーク圧は非耳痛群の 4 倍強の陽圧にあること から, 耳痛の原因は中耳腔の陽圧と推察した。興味深い 知見は下顎頭整位による中耳腔圧と反射閾值の変化であ る. 圧の変化量は対側耳で有意に大きく (表 4), 側差に も変化がみられた（表 5)。これらのことから，ピーク圧 の変化により耳痛発症の有無や程度, 消退の判断の可能 性が示唆される。したがって耳痛群のティンパノグラム
の変化には, 非耳痛群とは異なる要因の関与が考えられ, われわれはアブミ骨筋の関与の有無について検討した。

耳小骨筋反射では, 耳痛群の反射闇值が有意に高く(表 6)，下顎頭整位により側差が有意に減少したことから（表 7), ピーク圧と反射閾值の変化には関連性があると考え られる．鼓膜が緊張すれば，通常は耳小骨連鎖が外側に 率引される. しかし耳痛群は有意に高い陽圧にあるため, その圧がアブミ骨底を内耳方向に圧迫し，アブミ骨筋は 伸展させられスパズムが生じ，反射閾值が上昇するので はないかと考えた. 太田黒ら 17) は中耳腔圧の上昇がアブ ミ骨底を内耳方向に押し出すと報告しており，松本ら ${ }^{18)}$ は症状の重度に従うアブミ骨筋のスパズムを報告し，大 河原 ${ }^{19)}$ は下顎頭偏位によりアブミ骨筋の反射閾值が上昇 し潜時 $\mathrm{L}_{1}$ が延長すると報告している.アブミ骨筋は一側 の刺激により両耳が収縮するため，患側耳のスパズムが 同時に対側耳の射閾值をも上昇させる可能性がある. 対側の中耳腔圧は常態にあるので，対側耳の測定によっ て耳痛群の反射閾值上昇が観察された（表 6) と考えら れた。 耳小骨筋反射測定時の音圧刺激は, 患側耳と対側 耳でアブミ骨筋に異なる作用を及ぼす可能性があり，こ の点についてはさらに検討する必要がある，下顎頭整位 によって，2 群いずれでもインピーダンスの側差が減少 するが，非耳痛群に圧変化はみられない（表 5)。これに 対して耳痛群では，ピーク圧や反射閾值の側差が有意に 減少し（表 5，7），中耳腔圧や感覚機能における両耳均 衡性が快復している．これらのことから，中耳腔圧変化 にアブミ骨筋の関与が推察され，それは対側耳の反射閾 值測定によって判断し得ると考えられる.

三叉神経障害が耳小骨筋反射に及ぼす影響について は, 症状の重度に従う波形振幅の減少 ${ }^{18)}$, 反射閾值の上 昇や潜時 $\mathrm{L}_{1}$ の延長 ${ }^{19}$ ，アブミ骨底に最も近い蝸牛基底回 転の外有毛細胞の可逆的機能変化 ${ }^{20)}$, 三叉神経節と蝸牛 神経核や上オリーブ核複合体との神経接続 ${ }^{889)}$ が報告さ れている。これらの報告はいずれも三叉神経の異常入力 が蝸牛の神経機能やアブミ骨筋の反射機能に変化を及ぼ すことを示唆している。一側の障害が対側耳に影響を及 ぼすとの興味深い報告がある．宮崎 ${ }^{21)}$ は，鼓膜小穿孔例 の多数に対側耳閉感が発症し，穿孔閉鎖直後に消失した と報告している，病因は異なるがわれわれと一致すると ころが多い，その機序について宮崎 ${ }^{211}$ は，われわれと同 様に原因は患側にあると認め，両耳間の中耳感覚の均衡 が崩れるためと推測している，耳痛群における治療前の 
反射闇值の有意な上昇や下顎頭整位による側差の有意な 減少は, 宮崎 ${ }^{21)}$ のいう中耳感覚の均衡の崩れや可逆的変 化を示唆すると考えられる.

以上のことから，顎関節症による耳痛発症はアブミ骨 筋が関与することで生じる中耳腔の陽圧化と考えられ， 対側耳反射閾值測定により判断の可能性が示唆される.

\section{まとめ}

耳痛併発の顎関節症には，特徴的な下顎頭偏位が観察 された. 耳痛発症は，このねじれと推察される下顎頭位 の異常が顎関節からの侵害刺激となって中耳腔の陽圧を 発生させるためと考えられた．陽圧発生にアブミ骨筋の スパズムが推測され，対側耳の反射閾值測定による把握 の可能性が示唆された.

\section{謝 辞}

耳鼻咽喉科学の立場からご校閲，ご助言を賜った松戸歯学部 頭頸部外科・耳鼻咽喉科学 鈴木邦夫教授ならびに耳鼻咽喉科 臨床の立場からご校閲戴いた浜野 嚴先生に事心より感謝しま す.

本研究は, 日本学術会議 50 周年記念咬合学研連シンポジウム 「生命科学における咬合一咬合と全身のかかわりを探る一」（東 京, 2000. ) で発表し, 私立大学学術フロンティア共同研究プロ ジェクト「加㱓に伴ら口腔機能の発達と維持機能の解明」の研 究助成を受け, 高度先進医療「耳鼻咽喉領域における機能障害 を伴った顎関節症に対する中耳伝音系を指標とした顎位決定 法」(厚生労働省・高度先進医療審査委員会 平成 14 年 12 月承 認）の実績の一部となったことを付記し，関係各位に深く感謝 します。

\section{参考文献}

1) Keersmaekers K, De Boever JA and Van Den Berghe L : Otalgia in patients with temporo-mandibular joint disorders. $\mathrm{J}$ Prosthet Dent $75: 72 \sim 76,1996$.

2) Fee WEJr, Dirks DD and Morgan DE : Nonacoustic stimulation of the middle ear muscle reflex. Ann Otol Rhinol Laryngol $84: 80 \sim 87,1975$.

3) Ash CM and Pinto OF : The TMJ and the middle ear; structure and functional correlates for aural symptoms associated with temporomandibular joint dysfunction. Int J Prosthodont $4: 51$ $\sim 57,1991$.

4) Ioannides CA and Hoogrand GA : The disco-malleolar ligament; a possible cause of subjective hearing loss in patients with temporomandibular joint dysfunction. J Maxillofac Surg $11: 227 \sim 231,1983$.

5) Arlen $\mathrm{H}$ : The otomandibular syndrome. Clinical Management of Head, Neck and TMJ Pain and Dysfunction (ed by Gelb H). pp 181 194, Saunders Publishing Co Inc, Philadelphia, 1977.

6) Ciancaglini R, Loreti $P$ and Radaelli G : Ear, nose, and throat symptoms in patients with TMD; the association of symptoms according to severity of arthropathy. J Orofac Pain $8: 293 \sim$ 297, 1994

7）松本敏彦，小林久純，佐藤 扇，他：顎関節症における耳 症状と下顎頭偏位との関連. 日大歯学 74:737〜 741, 2000 .

8) Vass $Z$, Shore SE, Nuttall AL, et al. : Trigeminal ganglion innervation of the cochlea; a rentrograde transport study. Neuroscience $79: 605 \sim 615,1997$.

9) Shore SE, Vass $Z$, Wys NL, et al. : Trigeminal ganglion innervated the auditory braine stem. J Comp Neurol $419: 271 \sim$ 285,2000 .

10）小林義典, 松本敏彦, 石上恵一, 他 : 咬合と全身の機能と の関係. 補綴誌 $40: 1 \sim 23,1996$.

11）飯塚忠彦（監修）：顎関節症診療に関するガイドライン. 1 ～ 7 頁, $28 \sim 30$ 頁, 日本顎関節学会, 2001 .

12）高田敬子，松平登志正，山下公一：Tympanogram が Ad 型 の耳における耳小骨筋反射の検討. Audiology Jpn 36:625 $\sim 626,1993$.

13）田沼達也, 松本敏彦 : 側方運動の誘導要素と中耳機能との 連繋. 日大口腔科学 $22: 1 \sim 9,1996$.

14) Atkinson $\mathrm{WB}$ and Bates RE : The effect of the angle of the articular eminence on anterior disk displacement. J Prosthet Dent $49: 554 \sim 555,1983$.

15）松本敏彦：Tympanometry による顎機能異常の客観的評価. 補綴誌 $34: 1059 \sim 1065,1990$.

16）神崎 仁，野村恭也：インピーダンス オージオメトリー 聴覚障害と神経筋疾患への臨床応用. $75 \sim 86$ 頁, 中外医 学社, 東京, 1980 .

17）太田黒元，坂田俊文，今村明秀，他：tympanometry を用い た蝸牛小管の機能評価についての基礎的研究. 耳鼻 48:161 $\sim 174,2002$.

18）松本敏彦，成田紀之，小林久純，他：耳小骨筋反射による 顎機能異常の病態評価. 日大歯学 $68: 272 \sim 277,1994$.

19）大河原純也：下顎頭位が耳小骨筋反射の閾值，潜時に及ぼ す影響. 日大口腔科学 $24: 79 \sim 86,1998$.

20）菊池康視：歪成分耳音響放射による顎機能障害の客観的評 価. 日大口腔科学 $26: 139 \sim 145,2000$.

21）宮崎 誠：外傷性鼓膜穿孔と反対側耳閉感. 耳鼻臨床 90 : $1101 \sim 1109$, 1997.

原稿受付：平成14年10月 8 日 原稿採択 : 平成14年12月 6 日 急載 別刷請求先 : 松本敏彦 厂271-8587 松戸市栄町西2-870-1 日本大学松戸歯学部補綴学第三講座 